\title{
Patogenisitas Metarhizium huainamdangense Isolat Dumoga Timur Terhadap Wereng Batang Coklat (Nilaparvata lugens) Pada Tanaman Padi Sawah
}

\section{(Pathogenicity Of Metarhizium huainamdangense Isolates From Dumoga, Bolaang Mongondow District Against Brown Planthopper (Nilaparvata lugens) In Paddy Fields)}

\author{
Jusak Wongkar ${ }^{1,2)}{ }^{*}$, Dantje Tarore ${ }^{1)}$, Jimmy Rimbing ${ }^{1)}$ \\ $\left.{ }^{1}\right)$ Balai Perlindungan dan Pengujian Mutu Tanaman Pangan dan Hortikultura (BPPMTPH) Provinsi \\ Sulawesi Utara \\ 2) Program Studi Entomologi Pascasarjana Universitas Sam Ratulangi, Manado \\ *Email korespondensi: jusaknwongkar@gmail.com
}

(Article History: Received Dec 20, 2021; Revised Jan 20, 2022; Accepted Feb 2, 2022)

\begin{abstract}
ABSTRAK
Wereng coklat telah dilaporkan resisten terhadap berbagai jenis insektisida. Salah satu pengendalian yang ramah lingkungan, yaitu dengan penggunaan jamur entomopatogen. Penelitian ini bertujuan untuk menguji keefektifan jamur entomopatogen M. huainamdangense isolat lokal terhadap wereng coklat. Pengujian patogenisitas isolat lokal M. huainamdangense menggunakan Rancangan Acak Lengkap (RAL) dengan lima perlakuan yaitu perlakuan K1 (Kerapatan $\left.10^{6}\right)$, K2 (Kerapatan 107), K3 $\left(\right.$ Kerapatan $\left.10^{8}\right), K 4\left(\right.$ Kerapatan $\left.10^{9}\right)$ dan KO sebagai kontrol. Setiap perlakuan diulang 5 (lima) kali. Hasil penelitian menunjukkan bahwa perlakuan yang paling cepat mematikan serangga hingga 100\% yaitu pada perlakuan $K 4$ (Kerapatan $10^{9}$ ). Hasil analisis probit menunjukkan nilai LT50 pada perlakuan kerapatan konidium $10^{9}$ (K4) yaitu pada 1,6 hari, sedangkan nilai LC50 menunjukkan konsentrasi $10^{8,9}$ konidium/ml pada hari kedua. Penggunaan konsentrasi kerapatan konidia yang lebih rendah mampu mematikan 50\% serangga dalam waktu yang lebih lama.
\end{abstract}

Kata kunci: Metarhizium huainamdangense; entomopatogen; Nilaparvata lugens

\section{ABSTRACT}

Brown planthoppers have been reported to be resistant to various types of insecticides. One of the environmentally friendly controls is the use of entomopathogenic fungi. This study aims to test the effectiveness of the entomopathogenic fungus M. huainamdangense local isolates against brown planthoppers. Pathogenicity testing of local isolates of $M$. huainamdangense used a completely randomized design $(C R D)$ with five treatments, namely $K 1\left(\right.$ Density $\left.10^{6}\right), K 2\left(\right.$ Density $\left.10^{7}\right), K 3$ (Density $10^{8}$ ), K4 (Density $10^{9}$ ) and KO as control. Each treatment was repeated 5 (five) times. The results showed that the fastest treatment to kill insects up to $100 \%$ was in the K4 treatment (density $\left.10^{9}\right)$. The results of the probit analysis showed the LT50 value in the conidium density treatment $10^{9}$ (K4) at 1.6 days. Meanwhile, the LC50 value showed a concentration of $10^{8.9}$ conidium $/ \mathrm{ml}$ on the second day. The use of a lower concentration of conidia density was able to kill $50 \%$ of insects in a longer time.

Keywords: Metarhizium huainamdangense; entomopathogen; Nilaparvata lugens

\section{PENDAHULUAN}

Padi merupakan komoditas penting dalam pemenuhan konsumsi beras bagi sebagian besar penduduk Indonesia. Padi adalah salah satu bahan makanan yang mengandung gizi dan penguat yang cukup bagi tubuh manusia, sebab di dalamnya terkandung bahan yang mudah diubah menjadi energi (Anonim 2011; Kurnianti
2013). Padi dibudidayakan dengan tujuan mendapatkan hasil yang setinggi-tinginya dengan kualitas sebaik mungkin, untuk mendapatkan hasil yang sesuai dengan harapan maka tanaman yang akan ditanam harus sehat dan subur.

Tanaman yang sehat ialah tanaman yang tidak terserang oleh hama dan penyakit, tidak mengalami defisiensi hara, baik unsur 
hara yang diperlukan dalam jumlah besar maupun dalam jumlah kecil. Hampir di setiap musim terjadi ledakan hama pada pertanaman padi. Hama utama tanaman padi antara lain adalah tikus, penggerek batang padi, dan wereng batang coklat. Wereng batang coklat (Nilaparvata lugens) merupakan hama yang sangat merugikan perpadian di Indonesia, dengan serangannya yang dapat menyebabkan puso pada areal yang luas dalam waktu yang singkat. Hama ini mudah beradaptasi membentuk biotipe baru dan dapat mentransfer virus kerdil hampa dan virus kerdil rumput yang daya rusaknya lebih hebat dari hama wereng batang coklat itu sendiri (Tandiabang et al. 2001; IRRI 2003; Widiarta et al. 2004).

Pengendalian wereng batang coklat oleh petani biasanya menggunakan insektisida, namun jika digunakan secara berlebihan maka akan menimbulkan dampak negatif seperti resistensi, resurgensi, dan eksplosi. Untuk mengatasi permasalahan tersebut perlu alternatif pengendalian yang relatif lebih aman, baik bagi musuh alami, petani, produk yang dihasilkan, serta lingkungan sekitarnya. Pemanfaatan agens hayati diharapkan menggunakan dan juga dapat mengembangkan musuh alami yang spesifik lokasi. Pengendalian hayati dengan memanfaatkan jamur entomopatogen berpotensi untuk dikembangkan. Salah satu jenis jamur entomopatogenik yang terbukti cukup efektif mengendalikan hama wereng batang coklat adalah jamur Metarhizium anisopliae, jamur ini telah banyak digunakan di berbagai tempat di Indonesia. Secara alami di Dumoga Timur juga terdapat jamur entomopatogen akan tetapi baru-baru ini diketahui bahwa spesiesnya berbeda dengan Metarhizium di daerah lain. Berdasarkan hasil uji genetik yang dilakukan oleh Jusak et al. (2021) terhadap jamur yang disiolasi dari wereng batang coklat ternyata jamur tersebut adalah spesies M. Huainamdangense. Spesies ini belum pernah dilaporkan ditemukan di Indoensia namun spesies ini pernah ditemukan di Thailand. Sampai saat ini belum ada laporan tentang kemampuan jamur $M$. huainamdangense terhadap wereng batang coklat ( $N$. lugens) terutama dari daerah Dumoga Timur, karena jamur ini merupakan isolat lokal yang spesifik. Berdasarkan hal tersebut maka perlu dilakukan penelitian untuk menganalisis patogenisitas dari jamur $M$. huainamdangense terhadap wereng batang coklat ( $N$. lugens) pada tanaman padi sawah.

\section{METODE}

\section{Waktu dan Tempat Penelitian}

Penelitian dilaksanakan pada bulan Maret 2021 sampai dengan Juni 2021. Eksplorasi jamur dilakukan di pertanaman padi sawah di desa Kembang Sari Kecamatan Dumoga Timur Kabupaten Bolaang Mongondow. Kemudian penelitian dilanjutkan pada tahap isolasi, identifikasi, dan uji patogenisitas di Laboratorium Agens Hayati, Balai Perlindungan dan Pengujian Mutu Tanaman Pangan dan Hortikultura (BPPMTPH) Provinsi Sulawesi Utara.

\section{Alat dan Bahan}

Bahan dan alat yang digunakan dalam penelitian ini adalah benih tanaman padi, imago Nilaparvata lugens, beras, Potato Dextrose Agar (PDA), alkohol $70 \%$, chloramphenicol $250 \mathrm{mg}$, tissue, aquades steril, haemocytometer, colony counter, jarum ose, petridish, object glass, deck glass, tabung reaksi, aspirator, gelas ukur, autoclave, plastik, mikroskop, jet sprayer dan alat-tulis menulis.

\section{Prosedur Penelitian}

Rancangan yang digunakan dalam penelitian ini adalah Rancangan Acak Lengkap (RAL) yang terdiri dari 4 (empat perlakuan ) yaitu:

k0 : 0 (kontrol, hanya air, tanpa pemberian konidium)

$\mathrm{k} 1: 10^{6}$ konidium $/ \mathrm{ml}$

$\mathrm{k} 2: 10^{7}$ konidium $/ \mathrm{ml}$

k3 $: 10^{8}$ konidium $/ \mathrm{ml}$

$\mathrm{k} 4: 10^{9}$ konidium $/ \mathrm{ml}$

Masing-masing perlakuan diulang sebanyak 5 (lima) dan tiap ulangan terdiri 
dari 50 serangga yang diletakkan pada tiap ember yang berbeda.

\section{Isolasi dan Perbanyakan Jamur $M$. huainamdangense}

Jamur yang ada di permukaan tubuh serangga diambil dengan jarum ose dan dibiakan pada media PDA (Potato Dextrose Agar) hingga murni, yang selanjutnya diidentifikasi molekuler PCR dengan hasil yang didapatkan yaitu $99,65 \%$ mirip dengan spesies $M$. huainamdangense. Isolat jamur yang telah murni selanjutnya dilakukan perbanyakan massal jamur $M$. huainamdangense dengan menumbuhkan konidia jamur pada media beras. Inokulasi jamur dilakukan dengan cara mengambil kira-kira $1 \mathrm{~cm}^{2}$ konidia dan miselia pada PDA (hasil isolasi dan identifikasi) dan menginokulasikannya pada permukaan media beras, kemudian diinkubasikan pada suhu kamar selama 21 hari, sampai seluruh bagian permukaan media beras ditumbuhi miselia dan konidia jamur (ISO 2015).

\section{Pembuatan Suspensi Uji Penghitungan Kerapatan Konidia}

Konidia jamur yang telah tumbuh pada media beras diambil, kemudian dikocok ke dalam $100 \mathrm{ml}$ air sehingga menghasilkan suspensi jamur $M$ huainamdangense. Suspensi jamur $M$. huainamdangense diencerkan secara bertingkat untuk mendapatkan empat konsentrasi suspensi uji yaitu $10^{6}, 10^{7}, 10^{8}$, dan $10^{9}$ konidia $/ \mathrm{ml}$. Penghitungan jumlah konidia dilakukan dengan cara meneteskan suspensi konidia haemocytometer dan diamati di bawah mikroskop compound dengan perbesaran 400 kali.

\section{Penyediaan Serangga Uji dan Uji Patogenisitas Jamur}

Nimfa dan imago $N$. lugens diambil pada pertanaman padi sawah di Kecamatan Dumoga Timur Kabupaten Bolaang Mongondow dengan cara menggunakan aspirator kemudian serangga dipelihara dan diperbanyak di dalam kurungan kasa berukuran $50 \mathrm{~cm} \quad$ x $50 \quad \mathrm{~cm} \quad$ x $70 \quad \mathrm{~cm}$.
Serangga uji yang telah berumur 18-20 hari dipilih yang sehat sebanyak 50 ekor untuk tiap ulangan perlakuan dan ditempatkan pada kotak kurungan kasa uji patogenisitas yang di dalamnya terdapat tanaman padi yang ditumbuhkan pada wadah ember plastik. Selanjutnya serangga uji yang ada diaplikasikan dengan suspensi jamur $M$. huainamdangense dengan cara menyemprotkan sebanyak lima kali untuk tiap ulangan dengan menggunakan jet sprayer. Kemudian dilakukan pengamatan mortalitas serangga uji setiap hari dimulai dari satu hari setelah aplikasi sampai mencapai persentase mortalitas $100 \%$.

\section{Analisis Data}

Analisis data untuk pengamatan morfologi dengan cara mendiskripsikan ciriciri morfologinya dan menghitung kerapatan spora dengan rumus:

$\mathrm{S}=\frac{\bar{X}}{\mathrm{~L} \times \mathrm{t} \times \mathrm{d}} \times 10^{3}$

Keterangan :

$\mathrm{S}=$ kerapatan konidium $/ \mathrm{ml}$

$\mathrm{X}^{-}=$rerata jumlah konidium pada kotak a,b,c,d,e

$\mathrm{L}=$ luas kotak hitung $0,04 \mathrm{~mm}^{2}$

$\mathrm{t}=$ kedalaman bidang hitung $0,1 \mathrm{~mm}$

$\mathrm{d}=$ faktor pengenceran

$10^{3}=$ volume suspensi yang dihitung $(1 \mathrm{ml}=$ $10^{3} \mathrm{~mm}^{3}$ )

Untuk mencari nilai Lethal Concentration 50 (LC50) dan Lethal Time 50 (LT50) dihitung menggunakan analisis probit dengan menggunakan program aplikasi microsoft excel. Data hasil uji patogenisitas dianalisis dengan Uji Anava pada taraf $95 \%$ dan akan dilanjutkan dengan uji beda nyata terkecil pada taraf kepercayaan $5 \%$.

\section{HASIL DAN PEMBAHASAN Mortalitas}

Pada Gambar 1 dapat dilihat rata-rata mortalitas dari wereng batang coklat $(N$. lugens) setelah diaplikasikan beberapa perlakuan isolat jamur $M$. 
huainamdangense, yang menunjukkan adanya perbedaan mortalitas dari satu hari setelah perlakuan (HSP) sampai tujuh HSP. Pada satu HSP perlakuan dengan kerapatan konidium $10^{8}$ (K3) dan $10^{9}$ (K4) sudah mampu menyebabkan kematian lebih dari $25 \%$ dibandingkan dengan perlakuan kerapatan konidium $10^{6}(\mathrm{~K} 1)$ dan $10^{7}(\mathrm{~K} 2)$ yang pada satu HSP hanya mampu menyebabkan kematian kurang dari $25 \%$. Pada ketiga HSP juga dapat dilihat adanya perbedaan yang jauh antar tiap perlakuan, yang dimana perlakuan dengan kerapatan konidium $10^{9}$ (K4) mortalitasnya sudah mencapai lebih dari $80 \%$, berbeda dengan perlakuan kerapatan konidium $10^{7}$ (K3) dan $10^{8}$ (K4) yang pada tiga HSP mampu menyebabkan kematian lebih dari $70 \%$. Sedangkan untuk perlakuan kerapatan konidium $10^{6}(\mathrm{~K} 1)$ pada tiga HSP hanya mampu mematikan serangga $48 \%$.

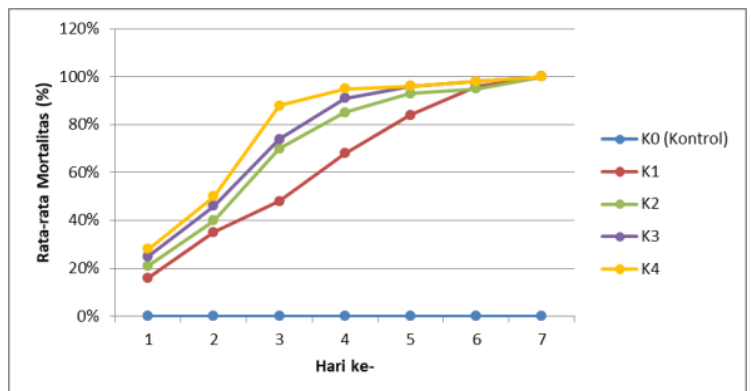

Gambar 1. Grafik persentase mortalitas wereng batang coklat ( $N$. lugens) setelah aplikasi beberapa isolat $M$. huainamdangense.

Perbedaan mortalitas ini diduga terjadi akibat tingkat kerapatan konidium yang lebih tinggi sehingga memicu mortalitas dari serangga hama wereng batang coklat $(N$. lugens) semakin cepat, dibandingkan dengan tingkat kerapatan konidium yang lebih rendah. Hal ini sesuai dengan pernyataan Soetopo (2004) yang menunjukkan bahwa viabilitas spora jamur yang tinggi menyebabkan mortalitas serangga yang tinggi. Berdasarkan hasil mortalitas yang ada, menunjukkan bahwa dengan hanya membutuhkan waktu enam sampai tujuh hari sudah mampu mematikan 90-100\% serangga. Zakharia 2019 melaporkan bahwa $M$. anisopliae paling efektif mematikan wereng batang coklat pada konsntrasi $1 \mathrm{~g} /$ $100 \mathrm{ml}$ dengan tingkat mortalitas 67,5\%. Perbedaan mortalitas dapat disebabkan oleh pengaruh kondisi konidia dan virulensi suatu jamur (Dumas et al. 1996).

\section{Lethal Time 50 (LT50) dan Lethal Consentration 50 (LC50)}

Hasil uji patogenisitas dari jamur entomopatogen $\quad M$. huainamdangense berdasarkan nilai LT50 dan LC50 dapat dilihat pada tabel 1. Hasil analisis probit menunjukkan nilai LT50 pada perlakuan kerapatan konidium $10^{6}(\mathrm{~K} 1), 10^{7}(\mathrm{~K} 2), 10^{8}$ (K3), dan $10^{9}$ (K4) secara berturut-turut yaitu 2,3 hari; 1,9 hari; 1,7 hari; dan 1,6 hari. Berdasarkan nilai LT50 yang ada, perlakuan dengan kerapatan konidium $10^{9}$ konidium/ml lebih cepat mematikan 50\% serangga yaitu hanya membutuhkan waktu selama 1,6 hari (Tabel 1). Hasil penelitian ini menunjukkan bahwa tidak adanya perbedaan waktu yang sangat jauh antara masing-masing konsentrasi kerapatan konidium yaitu hanya berkisar satu sampai dua hari. Hal ini dipengaruhi oleh sifat bawaan strain isolat dan juga viabilitas spora isolat (Herlinda et al. 2008).

Tabel 1. Nilai LT50 dan LC50 perlakuan isolat $M$. huainmdangense pada Wereng batang coklat (N. lugens)

\begin{tabular}{lccc} 
Serangga & Konsentrasi & $\begin{array}{c}\mathrm{LT}_{50} \\
(\text { Hari })\end{array}$ & $\begin{array}{c}\mathrm{LC}_{50} \\
(\text { Konidium/ml })\end{array}$ \\
& $1 \times 10^{6}$ & 2,3 & \\
N. lugens & $1 \times 10^{7}$ & 1,9 & 8,9 \\
& $1 \times 10^{8}$ & 1,7 & \\
& $1 \times 10^{9}$ & 1,6 & \\
\hline
\end{tabular}

Patogenisitas dari suatu entomopatogen juga dapat dilihat dari nilai LC50. Berdasarkan hasil analisis probit pada tabel 1, konsentrasi kerapatan konidium yang dapat mematikan $50 \%$ serangga yaitu pada konsentrasi $10^{8,9}$ konidium $/ \mathrm{ml}$ pada hari kedua. Hal ini menunjukkan bahwa untuk mematikan $50 \%$ serangga membutuhkan konsentrasi yang cukup tinggi dari penggunaan isolat lokal ini. Menurut Untung (2010), konsentrasi kerapatan konidia yang tinggi dapat berpotensi bagi konidia untuk melakukan penetrasi ke dalam tubuh 
serangga dan membentuk blastospora yang lebih banyak sehingga akan menyebar lebih cepat dan mengakibatkan serangga mati. Penggunaan konsentrasi kerapatan konidia yang lebih rendah mampu mematikan $50 \%$ serangga tetapi dalam waktu yang lebih lama, hal ini disebabkan oleh karena kerapatan konidia yang sedikit sehingga waktu infeksi menjadi lebih lama.

\section{Persentase Mortalitas Pada Hari Kedua}

Hasil analisis rata-rata persentase mortalitas wereng batang coklat ( $N$. lugens) pada hari kedua menunjukkan adanya perbedaan pada mortalitas (Gambar 2). Perlakuan kerapatan konidium $10^{6}$ (K1) tidak berbeda nyata dengan konsentrasi kerapatan konidium $10^{7}$ (K2) dan $10^{8}(\mathrm{~K} 3)$, tetapi sangat berbeda nyata dengan kontrol (K0). Sedangkan perlakuan kerapatan konidium $10^{8}$ (K3) tidak berbeda nyata dengan kerapatan konidium $10^{9}(\mathrm{~K} 4)$, tetapi kerapatan konidium $10^{9}(\mathrm{~K} 4)$ berbeda nyata dengan perlakuan kerapatan konidium lainya yaitu K1, K2, K3, dan K0. Berdasarkan hasil pengamatan yang diperoleh, menunjukkan bahwa semakin tinggi kerapatan konidia maka semakin tinggi juga tingkat mortalitas yang didapat. Hal ini terlihat dari besarnya perbedaan mortalitas yang tinggi antara kerapatan konidia paling tinggi yaitu $10^{9}$ konidium $/ \mathrm{ml}$ dengan kerapatan konidia paling rendah yaitu $10^{6}$ konidium $/ \mathrm{ml}$.

Kematian dari serangga hama wereng batang coklat (N. lugens) hanya membutuhkan waktu enam hari untuk mematikan $100 \%$ serangga. Namun, pada waktu serangga mati pada satu HSP belum terlihat adanya ciri-ciri pertumbuhan jamur seperti tumbuhnya miselium jamur $M$. huainamdangense. Miselium dari jamur $M$. huainamdengense pertama kali muncul pada hari keempat dengan memiliki ciri-ciri yaitu berwarna putih pada tahap vegetatif, yang lama-kelamaan akan berubah menjadi warna hijau pucat pada tahap generatif dan pertumbuhan miselium terlihat hampir pada seluruh permukaan tubuh serangga yaitu pada bagian kepala, tungkai, sayap, dan abdomen (gambar 3). Hal ini sesuai dengan penelitian yang telah dilaporkan oleh Suryadi dan Kadir (2007) yang menyatakan bahwa tubuh serangga wereng batang coklat yang terinfeksi memiliki ciri-ciri miselium yang berwarna kehijau-hijauan dan sebaran konidianya tidak merata.

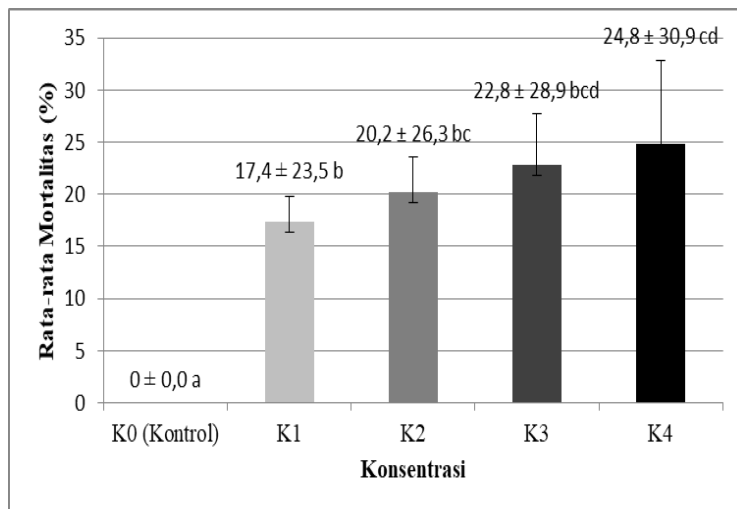

Gambar 2. Hasil analisis terhadap persentase kematian pada hari kedua. Huruf kecil yang sama di atas bar menunjukkan tidak berbeda nyata berdasar uji BNT pada $\alpha 5 \%$.
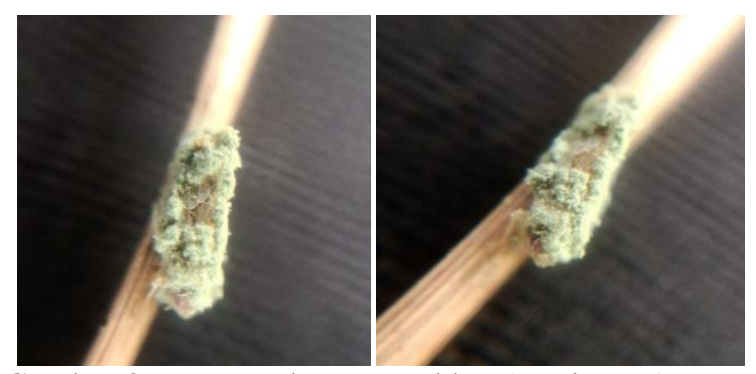

Gambar 3. Wereng batang coklat ( $N$. lugens) yang dikolonisasi miselium jamur $M$. huainamdangense.

\section{KESIMPULAN}

Jamur entomopatogen isolat Dumoga Timur yang menyerang wereng batang coklat ( $N$. Lugens) merupakan jamur $M$. huainamdangense. Konsentrasi kerapatan konidium $10^{9}$ konidium $/ \mathrm{ml}$ sudah dapat menyebabkan mortalitas $100 \%$ wereng batang coklat ( $N$. lugens) pada hari kelima. Nilai $\mathrm{LT}_{50}$ yaitu hanya membutuhkan waktu dua hari, sedangkan untuk nilai LC50 pada konsentrasi $10^{8,9}$ konidium $/ \mathrm{ml}$. Hasil analisis rata-rata persentase mortalitas wereng batang coklat ( $N$. lugens) yang dilakukan pada hari kedua HSP dengan menggunakan uji anava menunjukkan adanya perbedaan pada mortalitas tiap perlakuan. Perlu 
dilakukan penelitian lebih lanjut jamur $M$. huainamdangense di laboratorium sebagai agens pengendali hayati wereng batang coklat (N. lugens) pada tanaman padi sawah.

\section{DAFTAR PUSTAKA}

Anonim (2011). http://cenHama Padi: Wereng dan Cara Penanggulangannya. tongkaleng.wordpress.com/2011/08/05/h ama-padi-wereng/

Dumas, CM. R, V Matha and A Vey (1996). Comparative study of the cytological aspects of the mode of action of destructions and other peptidic fungal metabolites on target epithetical cells. J. Invert. Pathol. 67,137-146.

Herlinda S, Mulyati SI, Suwandi (2008). Jamur Entomopatogen Berformulasi Cair sebagai Bioinsektisida untuk Pengendali Wereng Coklat. Agritrop 27(3):119-126.

IRRI (International Rice Research Institute) (2003). Masalah Lapang Hama, Penyakit, Hara pada Padi. IRRI. 71 hal.

ISO. 2015. Sistem Manajemen Mutu. Balai Perlindungan dan Pengujian Mutu Tanaman Pangan dan Hortikultura Laboratorium Agens Hayati (LAH) Kalasey

Kurnianti N (2013). Budidaya Tanaman

Padi Sawah.

http://petunjukbudidaya.blogspot.com/20 13/01/budidaya-tanaman-padisawah.html
Soetopo D (2004). Efficacy of selected Beauveria bassiana (Bals.) Vuill. isolates in combination with a resistant cotton variety (PSB-Ct 9) againts the cotton bollworm, Helicoverpa armigera (Hübner) (Lepidoptera: Noctuidae). [Disertasi]. Philippines: University of The Philippines Los Banos.

Zhakaria M.F. (2019) Uji Efektivitas Jamur Entomopatogen Metarhizium anisopliae Formulasi Tepung terhadap Wereng Coklat Nilaparvata lugens Stal (Homoptera: Delphacidae) pada Tanaman Padi. Skripsi. Fakultas Pertanian Universitas Jember. Jember.

Suryadi Y, dan Kadir TS (2007). Pengamatan Infeksi Jamur Patogen Serangga Metarhizium anisopliae (Metsch. Sorokin) Pada Wereng Coklat. Berita Biologi 8(6): 501-507.

Tandiabang, J., Koesnang \& A. Muis (2001). Fluktuasi populasi wereng hijau (Nephotettix virescens) dan intensitas penyakit tungro di Lanrang, Sidrap, Sulawesi Selatan. J. Fitopat. Ind. 5:2429.

Widiarta IN, Kusdiaman D, Siwi SS, \& Hasanuddin A (2004). Variasi efikasi penularan tungro oleh koloni-koloni wereng hijau Nephotettix virescens Distant. J. Entomol. Ind. 1:50-56.

Untung K (2000). Pengantar Pengelolaan Hama Terpadu. Gadjah MadaUniversity Press. Yogyakarta. 